\title{
Ağrılı ve sorunlu total kalça artroplastisi yönetimi
}

\section{Management of painful and problematic total hip artroplasty}

\author{
Mehmet Arazi ${ }^{1}$, Harun Kütahya ${ }^{2}$ \\ ${ }^{1}$ Özel Konya Farabi Hastanesi, Ortopedi ve Travmatoloji Kliniği, Konya \\ ${ }^{2}$ Konya Ticaret Odası Karatay Üniversitesi Tıp Fakültesi,Ortopedi ve Travmatoloji Ana Bilim Dalı, Konya
}

Total kalça artroplastisi (TKA), uygun seçilmiş hastalarda tekniğe uygun olarak yapıldığında, kısa ve uzun dönem takiplerde oldukça başarılı sonuçlar vermektedir. Günümüzde TKA uygulamaları sadece ülkemizde değil, tüm dünyada artan bir sıklıkta yapılmaya devam etmektedir. Bu da, revizyon sayısının her geçen gün artacağı anlamına gelir. Gelişmiş cerrahi teknikler ve modern implant tasarımlarına rağmen, hastaların bir kısmında kalıcı ağrı yakınmaları devam etmektedir. Bu hastalarda ağrı kaynağının bulunması için sistematik bir yol izlenmelidir. Asetabular komponentle ilgili sorunlar sıklıkla kasık ağrısına neden olurken, femoral komponentle ilgili sorunlar anterior uyluk ağrısı şeklinde ortaya çıkar. Trokanterik bölge ile ilgili sorunlar ise lateral kalça ağrısı yapar. Lomber omurga kaynaklı sorunlar ise posterior kalça ağrısına sebep olur. Ağrı kaynağı ortaya konmadan yapılacak cerrahi bir girişimin başarı şansı düşüktür. Ayırıcı tanıda; ayrıntılı fizik muayene, sedimantasyon, C-reaktif protein (CRP) ölçümleri ve direkt grafiler yardımcı olur. Bazı hastalarda eklem ponksiyonu, bilgisayarlı tomografi (BT), manyetik rezonans (MR) görüntüleme ve nadiren kemik sintigrafisi gibi tanı yöntemleri gerekli olabilir. Tedavi, ağrı kaynağının bulunması ile doğrudan ilişkilidir ve çoğu kez cerrahi yaklaşımlardan oluşur.

Anahtar sözcükler: total kalça artroplastisi; ağrı; aşınma; gevşeme; enfeksiyon
Total hip arthroplasty (THA) gives very successful results in short and long term follow-ups when it is performed in accordance with the technique in appropriately selected patients. Nowadays, THA applications continue to be performed with an increasing frequency not only in our country but also all over the world. This means that the number of revisions will increase progressively. Despite advanced surgical techniques and modern implant designs, some patients continue to complain about persistent hip pain. A systematic way to find the source of the pain should be followed in these patients. While problems with acetabular component often cause groin pain, femoral component presents as anterior mid-thigh pain. Problems with trochanteric region cause lateral hip pain. Problems originating from lumbar spine causes posterior hip or buttock pain. A surgical intervention without revealing the source of the pain has a low chance of success. Detailed physical examination, sedimentation, C-reactive protein (CRP) rates, and plain radiographs are helpful for differential diagnosis. In some patients, methods such as joint aspiration, computed tomography, magnetic resonance imaging, and rarely bone scanning may be necessary. Treatment is directly related to find source of the pain, and often consists of surgical approaches.

Key words: total hip arthroplasty; pain; wear; loosening; infection
E klem artroplastisi en başarılı ortopedik müdahalelerden biridir. Ağrıyı gidermek ve fonksiyonel kapasiteyi artırmak için yapılır. Total kalça artroplastisinin (TKA) en sık kullanıldığı endikasyonlar; kalça eklemini etkileyen semptomatik şiddetli osteoartrit ve osteoporoza bağlı kalça kırıklarıdır. Kalça artroplastisi uygulamaları sadece ülkemizde değil, tüm dünyada artan bir sıklıkta yapılmaya devam etmektedir. Bu da, mutlu hastalar yanında ağrısı geçmeyen mutsuz hastaların da daha çok karşımıza çıkacağı anlamına gelmektedir.

Uygun seçilmiş hastalarda tekniğe uygun olarak yapıIan TKA sonrası kısa ve uzun takiplerde oldukça başarıı sonuçlar bildirilmiştir. ${ }^{[1,2]}$ Mükemmel uzun dönem sonuçlarla birlikte; 10 yıllık sağkalımlar \%95'in üzerinde bildirilirken, 20 yıllık sağkalımlar \%80'in üzerindedir. ${ }^{[3]}$ Total kalça artroplastisi ameliyatlarının en önemli iki gereksinimi yerine getirmesi beklenir. Bunlar, ağrının giderilmesi ve kalça fonksiyonlarının geri kazanılmasıdır. ${ }^{[3]}$ Tüm iyileşmiş cerrahi teknikler ve modern tedavi yaklaşımlarına rağmen hastaların bir kısmında ağrı yakınması devam eder. Bu ağı kaynağının bulunması için sistematik bir yol izlenmelidir. Ağrı kaynağı ortaya konmadan yapılacak cerrahi girişimin başarı şansı düşüktür. Ağrılı kalça artroplastisinin oranları değişken olup $\% 0,4$ 'ten $\% 18$ 'lere kadar bildirilmektedir. ${ }^{[4-6]}$

İletişim / Contact: Prof. Dr. Mehmet Arazi • E-posta / E-mail: Mehmet.arazi@gmail.com

ORCID iD: Mehmet Arazi, 0000-0003-3630-667X • Harun Kütahya, 0000-0003-1322-3548 
Ağrılı kalça diyebilmek için ameliyattan sonra üç ay geçmiş olması önerilir. ${ }^{[5,6]}$ Bununla birlikte Erivan ve ark., bu süreyi altı ay olarak kabul etmişlerdir. Ağrılı kalça sergileyen hastalarda ağrının gerçek kaynağının bulunması çok önemlidir. Tedavinin başarısı, ağrı kaynağının doğru belirlenmesi ile doğrudan ilişkilidir. Ağrılı bir protez aynı zamanda, sosyal güvenlik sistemine ilave ekonomik bir yük oluşturur. ${ }^{[6]}$

Ağrının lokalizasyonu da sebebinin ayırt edilmesinde yararlıdır. Asetabular komponentle ilgili sorunlar sıklıkla kasık ağrısına neden olurken, femoral komponentle ilgili olanlar anterior uyluk ağrısı şeklinde ortaya çıkar. Trokanterik bölge ile ilgili sorunlar lateral kalça ağrısı yapar, lomber omurga kaynaklı olanlar ise posterior kalça ağrısına neden olur. Her zaman, yapılacak bir primer TKA ameliyatından önce iyi bir spinal muayene yapılması önerilir.

Ağrılı kalça nedenleri genel olarak, cerrahi kaynaklı olanlar ve olmayanlar şeklinde ikiye ayrılır. ${ }^{[4-6]}$ Bunun yanı sıra, ağıı kaynağı olabilecek tüm sebepler şöyle sıralanabiliri ${ }^{5-8]}$ :

1. Enfeksiyon

2. Eklem dışı ile ilgili sebepler
a. Lomber radikülopati
b. Spinal dar kanal
c. İnguinal herni
d. Tıkayıcı damarsal hastalıklar
e. Lomber ya da abdominal kitle varlığında, bası sonucu yansıyan radiküler ağrı
f. Psikolojik kökenli ağrı

3. Eklem çevresi ile ilgili sebepler
a. Trokanterik bursit
b. Iliopsoas tendinit
c. Abduktor yetmezlik
d. İskial tuberositas tendiniti
e. Heterotopik ossifikasyon

4. Instabilite

5. Kötü pozisyonda protez yerleştirilmesi (uzunluk eşitsizliği gibi)

6. Kemik sorunları (gevşeme, kırık)

7. Aşınma ve osteoliz

8. Materyal sorunları (Trunnionosis, metal-metal kullanımına bağlı sinovit)

9. Kompleks bölgesel ağrı sendromu

\section{ENFEIKSIYON}

Ağrılı bir kalça ile karşılaştığımızda ilk olarak aklımıza enfeksiyon gelmelidir. Enfeksiyon en sık görülen TKA sonrası ağrı sebebidir, dolayısıyla ilk önce enfeksiyon varlığı araştırılmalıdır. Enfeksiyonun ciddi ekonomik ve sosyal yükü vardır ve bir artroplasti ameliyatı için son derece kötü bir klinik durumu gösterir. Hastaların hareketliliği azalır, hayat kalitesi düşer, aynı zamanda mortalite artar..$^{[8]}$ Enfeksiyon varlığını değerlendirmek için öncelikle klinik muayene yapılır. Ateş yüksekliği ya da yara iyileşmesi problemleri ve açık sinus hattı kontrol edilmelidir. Özellikle düşük virulanslı ve düşük dereceli enfeksiyonlarda enfeksiyonun tek belirtisi, kronik devam eden sinsi ve anlaşılamayan kalça ağrısı olabilir. Bu sebeple, ağrılı her kalçadan öncelikle enfeksiyon varlığı ekarte edilmelidir. Sedimantasyon, beyaz küre sayısı ve C-reaktif protein (CRP) öncelikle değerlendirilmelidir. Bunun yanında, prokalsitonin ve lökosit işaretli sintigrafi de önerilen tetkik yöntemlerindendir. Eğer sedimantasyon ve CRP değerleri normalse, enfeksiyon varlığı \%90'ı aşan hassasiyetle ekarte edilir. ${ }^{[9]}$ Artmış değerler, enfeksiyon şüphesine işaret eder ve eklem içi aspirasyon ile eklem sıvısı tetkiki gerekliliği ortaya çıkar. Eklem sıvısında beyaz küre sayısının 3.966/ml'yi geçmesi ya da \%80'inin nötrofillerden oluşması, kronik eklem enfeksiyonu tanısı için eşik değeri kabul edilir. ${ }^{[8,10]}$ Eklem sıvısı; aerobik, aneorobik ve mantar için kültürlere gönderilir.

Enfeksiyonun araştırılmasında görüntüleme yöntemleri olarak direkt röntgen grafisi ile başlanır. Nötralde anteroposterior pelvis grafisi, gerçek lateral (cross table) kalça grafisi ve kurbağa pozisyonunda kalça grafisi alınmalıdır. İmplantlar çevresinde radyolüsen alanlar, periost reaksiyonları ve yeni kemik oluşumları enfeksiyon belirtileri olabilir (Şekil 1). Enfeksiyon tespit edilen hastalar tek ya da çift seanslı revizyonlar ile tedavi edilirler.

\section{EKLEM DIŞI NEDENLER}

Eklem dışı sebepler arasında en sık görülen, lomber dejeneratif hastalıklar sonrası gelişen, yansıyan kalça ağrılarıdır. Bu tip ağrı, çoğunlukla kalçanın arka bölümünde olur ve alt ekstremite boyunca distale doğru uzanma özelliğindedir. Sıklıkla, fizik muayenede siyatik sinir trasesi boyunca basarak hassas noktalar tespit edilir. Hastalarda nörolojik kladikasyo, ayaklarda uyuşma, karıncalanma gibi duysal yakınmalar da olabilir. Kalça osteoartriti oluşan yaşlı popülasyonda, buna sıklıkla bel problemleri de eşlik eder. Parvizi ve ark., kalça artroplastisi yapılan 344 hastanın neredeyse yarısında (\%49) ameliyattan önce bel ağrısı olduğunu rapor ettiler. ${ }^{[11]}$ Yazarlar, bu hastaların \%20 'sinde ameliyattan bir yıl sonra, daha önce olmadığı halde bel ağrısı başladığını gösterdiler. Toplumda bel problemleri \%75'lere kadar ulaşan yüksek bir oranla çok yaygındır. ${ }^{[11]} \mathrm{Bu}$ nedenle, gerek ameliyat öncesi dönemde gerekse ağrısı geçmeyen bir kalça artroplastisi olgusunda, ağrı kaynağının araştırılmasında lomber bölge ayrıntılı incelenmelidir. 


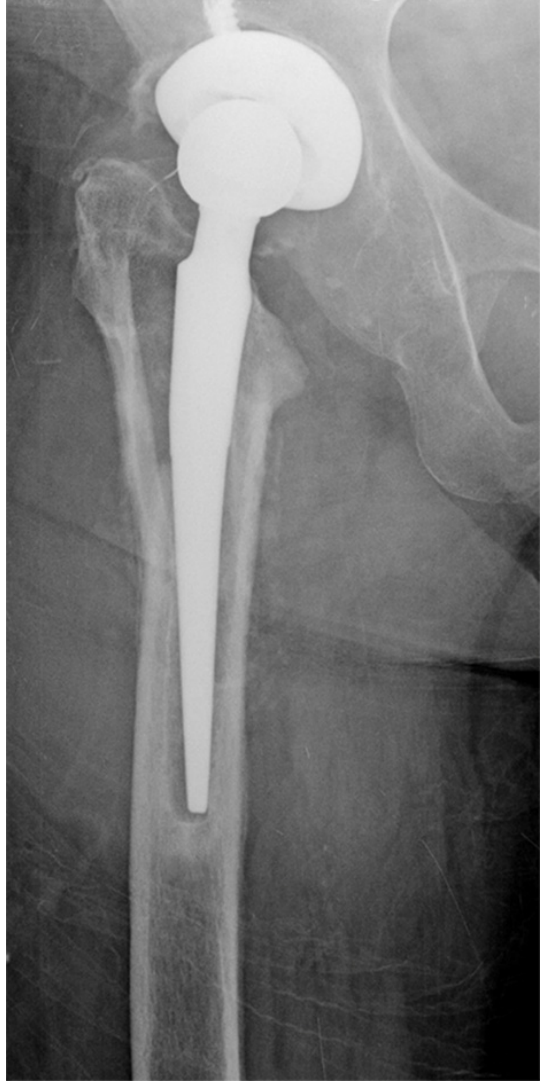

Şekil 1. Yetmiş altı yaşındaki kadın hastaya, yedi yıl önce çimentolu femur ve çimentosuz asetabular kap ile total kalça artroplastisi (TKA) ameliyatı yapılmış. Hasta sürekli ağrısının olduğunu belirtiyor. Röntgen grafisinde femoral komponentin tamamen gevşemiş, stem etrafında geniş boşluklar olduğu ve proksimal femurun medial duvarında enfeksiyon lehine periosteal düzensizlikler dikkat çekiyor.

Eklem dışı sebepler arasında; daha az sıklıkta görülen inguinal herni, tıkayıcı periferik damar hastalıkları, malign tümörlerin baskısı sonucu ortaya çıkan yayılıcı ağrılar ve psikolojik kökenli ağrılar da dikkate alınmaIıdır. ${ }^{[7]}$ Bazen tüm tetkik ve değerlendirmelere rağmen ağrının kaynağı bulunamayabilir. Erivan ve ark., 201 kalça artroplastisi hastasından yedisinde $(\% 3,5)$ tanı konulamadığını belirttiler. ${ }^{[6]}$

\section{EKLEM ÇEVRESI NEDENLER}

Ağrılı kalça artroplastisi, çok sık olmasa da zaman zaman, eklem çevresi sebeplerle olabilir. Erivan ve ark., 201 kalçanın içerisinde en sık trokanterik bursit (40 kalçada), daha az olarak da iliopsoas tendiniti (beş kalçada), abduktor yetmezlik (beş kalçada), heterotopik ossifikasyon (iki kalçada) ve iskial tuberositas tendiniti (bir kalçada) görüldügünü rapor ettiler. ${ }^{[6]}$
İliopsoas tendiniti ya da iliopsoas sıkışmasına bağlı kalça ağrısı, son yıllarda artan sıklıkta rapor edilmeye başlanmıştır. Bu hem metal-metal protezlerde hem de konvansiyonel kalça artroplastisinde görülebilir ve çoğunlukla, büyük ya da kemik kenarın dışına taşan asetabular kap, dışarı taşan çimento tahrişi, yine dışarı taşmış asetabular vida, normal femur başından daha büyük baş kullanılması, asetabular kafes kullanımı gibi sebeplerle birliktedir. ${ }^{[5,12]}$ Tendon problemleri, enfeksiyon ve lomber sorunların ardından araştırılması gereken önemli ağrı sebeplerindendir.

\section{İnstabilite}

Bariz instabilite, kalça artroplastisinde önemli bir mutsuzluk nedenidir ve uygun şekilde tedavi edilmelidir. Bazı olgularda instabilite açıkça klinik bulgu vermez ve kronik kalça ağrısına neden olabilir. Özellikle asetabular ya da femoral komponentlerin kötü pozisyonda yerleştirilmiş olması, kalçada kronik minör bir instabiliteye ve subluksasyona yol açar. Subluksasyon genellikle, kalçanın belirli pozisyonlarda aniden disloke olmaya çalışması ve yine hızlı bir şekilde spontan redükte olması olarak tanımlanır. Bu sırada şiddetli ağrı olur, bir klik sesi alınabilir. Majör dislokasyon çok araştırılmış iyi bilinen bir klinik durum iken, subluksasyon çok daha az çalışılmış bir konudur. Tanısı zordur ve subklinik bir tablo sergiler; sıklıkla gözden kaçar. Görülme sıklığı \%2-\%5,5 olarak bildirilmiştir. ${ }^{[8,13]}$ Stres testleri ya da genel anestezi altında muayene yapılabilir (Şekil 2). Instabilitelerin tedavisi sebebin ortaya konulması ve komponent pozisyonlarının iyi değerlendirilmesi ile planlanır. Majör çıkıklar revizyon gerektirirken subluksasyon olguları olgu bazında ele alınarak, koruyucu ortezler, egzersizler, zorlayıcı pozisyonlardan kaçınma gibi önlemlerle izlenebilir. Önemli klinik rahatsızlık sebebi olan subluksasyonlar, buna yönelik revizyon cerrahi tedaviler ile düzeltilir. ${ }^{[12]}$

\section{Kötü Pozisyonda Protez Yerleştirilmesi}

Bu hata, sıklıkla uzunluk eşitsizliği sorununa yol açar. Çimentosuz femoral stemlerin olması gerekenden daha büyük ölçüde seçilmesi ya da çimentolu komponentlerin yüksekte bırakılmasından kaynaklanır. Uzun kalça zamanla pelvik oblisiteye, kalça çevresinde kaslarda gerginliğe, ve ağrılı bir konforsuzluğa sebep olur (Şekil 3). Bacak uzunluğu eşitsizliği, sık görülen ameliyat sonrası komplikasyonlardan biridir ve çoğunlukla hekime karşı dava açılmasının önemli sebepleri arasında olduğu bilinir. ${ }^{[5,6,8]}$ Bir santimetreye kadar olan uzunluk farkı çoğu hasta tarafindan rahatlıkla tolere edilirken, $2 \mathrm{~cm}$ 'yi geçen bacak uzunluk farkı olan ağrılı hastalara cerrahi olarak revizyon önerilir (Şekil 4). Özellikle minyon yapıda, kısa boylu kadın hastalarda ve kalça displazisi zemininde yapılacak TKA ameliyatlarında, femoral kanalın küçük 

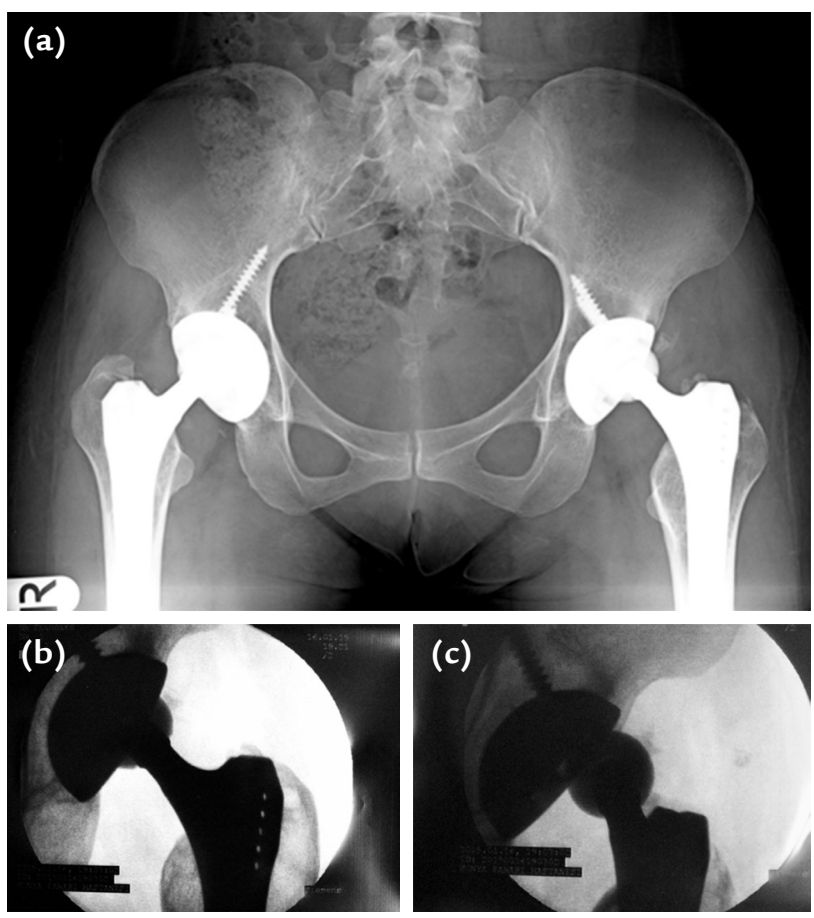

Şekil 2. a-c. Otuz yaşındaki kadın hastada, 10 yıl önce hematolojik hastalığa bağlı steroid tedavisi sonrası bilateral femur başı avasküler nekrozu gelişmiş. Hastaya, iki taraflı seramik-seramik eklemli çimentosuz total kalça artroplastisi (TKA) ameliyatı yapılmış. Klinik olarak tamamen sağlıklı iken hafif bir travma sonrası sol kalçasında ağrı tanımlıyor. Fizik muayenede, sol kalça hareketleri rahat ve tamamen ağrısız. Ön-arka pelvis grafisinde, her iki tarafta TKA görülmekte (a). Şüpheli instabilite ve seramik kırı̆̆ı sebebiyle genel anestezi altında muayene yapıldı (b, c). Kalçanın fleksiyon ve iç rotasyonunda, eklemin sublukse olduğu tespit edilerek revizyon kararı verildi (c).

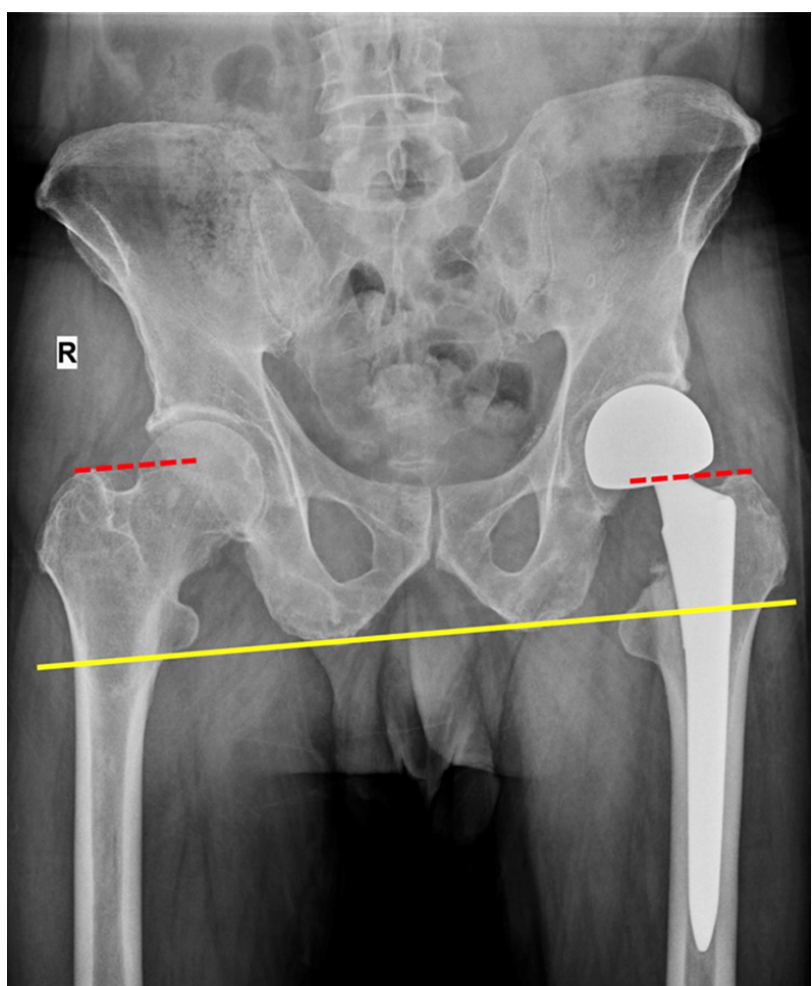

Şekil 3. Yetmiş dört yaşındaki erkek hastaya, dört ay önce düşmeye bağlı sol kalça femur boyun kırığı sebebiyle çimentosuz hemiartroplasti ameliyatı yapılmış. Hastanın ameliyattan sonra yürüme güçlüğü ve ağrı şikâyetleri devam etmiş. Pelvis grafisinde sol kalçanın uzun olduğu ve bunun pelvik oblisiteye yol açtığı görülüyor. Fizik muayenede; sol kalça hareketleri kısıtlı ve ağrılıydı, çift koltuk değneği ile yürümek istiyordu ve sol alt ekstremitede $2,5 \mathrm{~cm}$ uzunluk farkı vardı. Hastaya revizyon cerrahisi uygulandı.

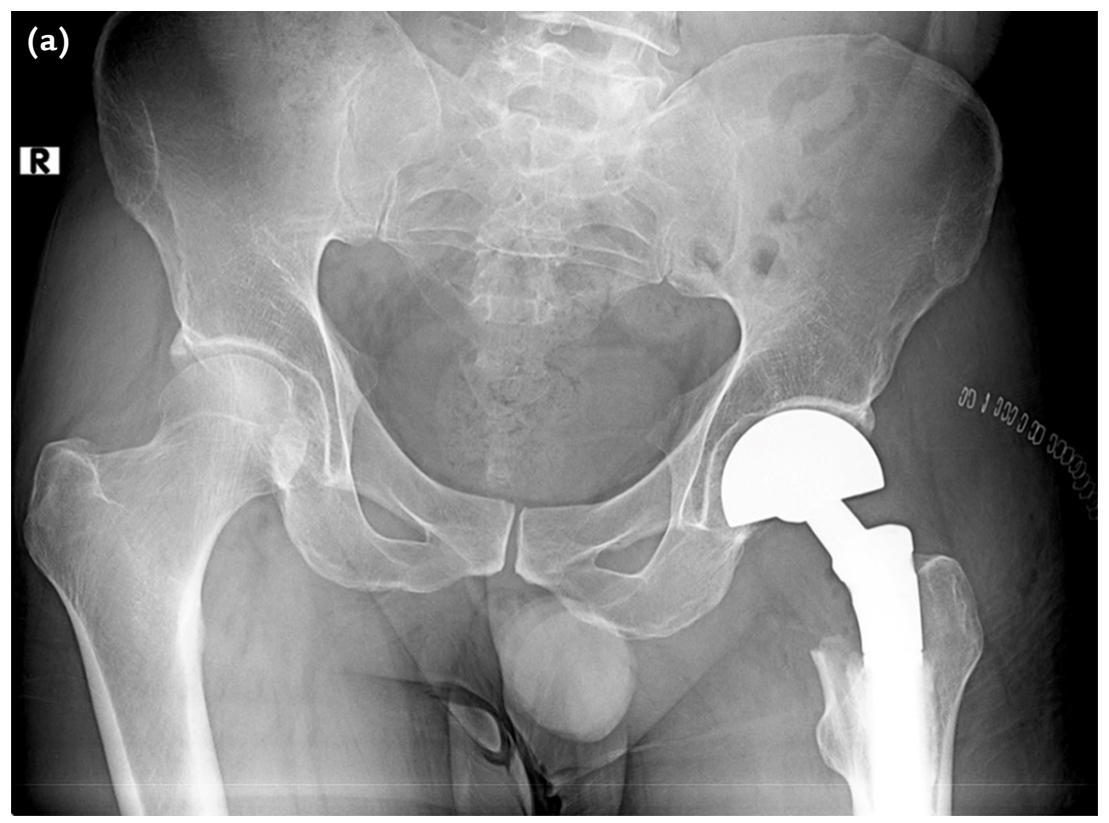

(b)

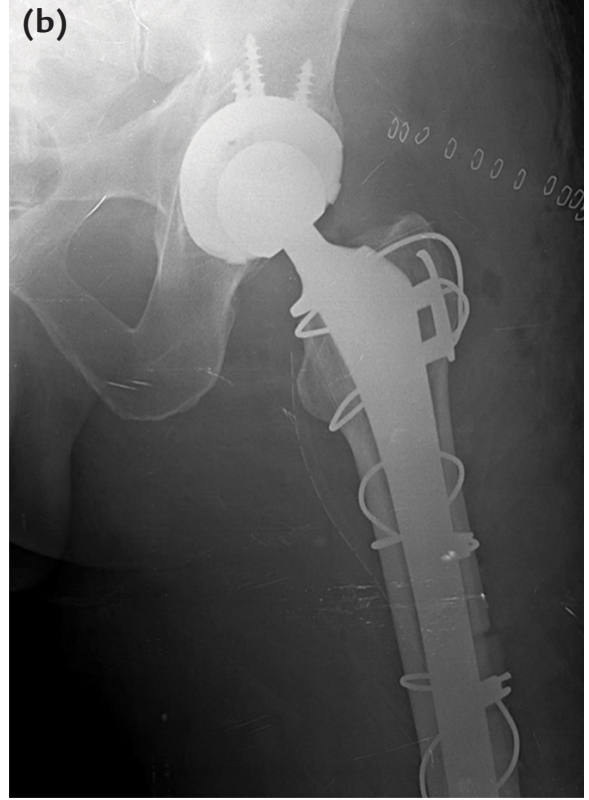

Şekil 4. a, b. Altmış beş yaşındaki erkek hastaya, bir ay önce düşmeye bağlı sol kalça femur boyun kırı̆̆ı sebebiyle çimentolu hemiartroplasti ameliyatı yapılmış. Röntgen grafısinde; femoral komponentin yüksekte kaldığı, ciddi uzunluk farkına bağlı pelvik oblisite geliştiği dikkat çekiyor (a). Hasta yürümekte zorlanıyordu, kalça hareketleri ciddi kısıtlıydı ve sol alt ekstremitede $3 \mathrm{~cm}$ uzunluk farkı vardı. Hasta, genişletilmiş trokanterik osteotomi yapılarak femoral komponent ve çimento çıkartılması sonrası revizyon total kalça artroplastisi (TKA) ile tedavi edildi (b). 


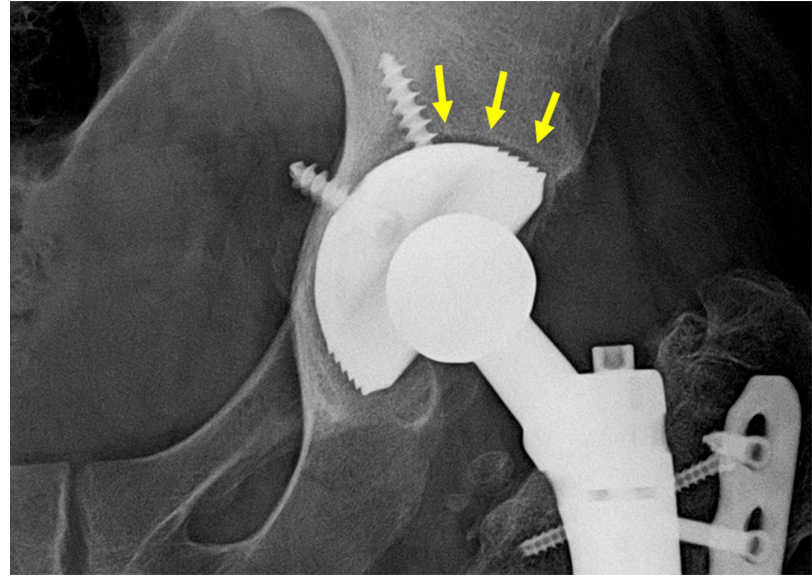

Şekil 5. Elli üç yaşındaki erkek hasta, iki yıl önce posttravmatik kalça artriti tanısı ile çimentosuz total kalça artroplastisi (TKA) ameliyatı yapılmış. Aksama ve aktivite ile artan kasık ağrısı şikâyetiyle müracaat etti. Röntgen grafisinde asetabular komponentin etrafinda gevşemeye işaret eden radyolüsen alanlar dikkat çekiyor (sarı oklar). Revizyon cerrahisinde asetabular komponent tamamen gevşekti. Hasta izole asetabular komponent revizyon cerrahisi ile tedavi edildi.

olma ihtimali göz önünde bulundurulmalı, ameliyatlara ekstra küçük femoral stemlerle girilmelidir. Günlük pratiğimizde, dar femoral kanala sahip hastaların az olmadığını gözlemliyoruz. Bu nedenle, tüm TKA ameliyatlarımız sırasında, ekstra küçük femoral komponentlerin de olduğu farklı marka ve modele sahip protezler hazır olmalıdır. Ameliyatın her aşamasında uzunluk eşitsizliği olasılığı dikkate alınarak basamaklar geçilmelidir.

\section{Kemik Sorunları (Aseptik Gevşeme, Protez Çevresi Kırık)}

Total kalça artroplastisi yapılan hastalarda kasık ağrısının bir diğer önemli sebebi aseptik asetabular komponent gevşemesidir. ${ }^{[5,12]} \mathrm{Bu}$, ciddi bir rahatsızlık verir, ayırt edilmesi önemlidir. Direkt grafiler çok bilgi verici olmayabilir. Bununla birlikte, değişik pozisyonlarda kalça grafilerinin çekilmesi ve iyi bir fizik muayene ile tanı konabilir (Şekil 5). Asetabular komponentin stabilitesi değişik faktörlere bağlıdır. Kemik kalitesi ile asetabular komponentin çapı ve malzeme özelliği primer stabilitede etkilidir. Olabildiğince dikkatli asetabular oyma ve press-fit çakmaya özen gösterilmelidir (Şekil 6). Çoğunlukla vidasız press-fit oturan komponentler gevşer. ${ }^{[12,14,15]}$ Asetabular gevşemede ağrı, tipik olarak tam kasıkta olur ve hareketle birlikte artar. İstirahatte hastalar

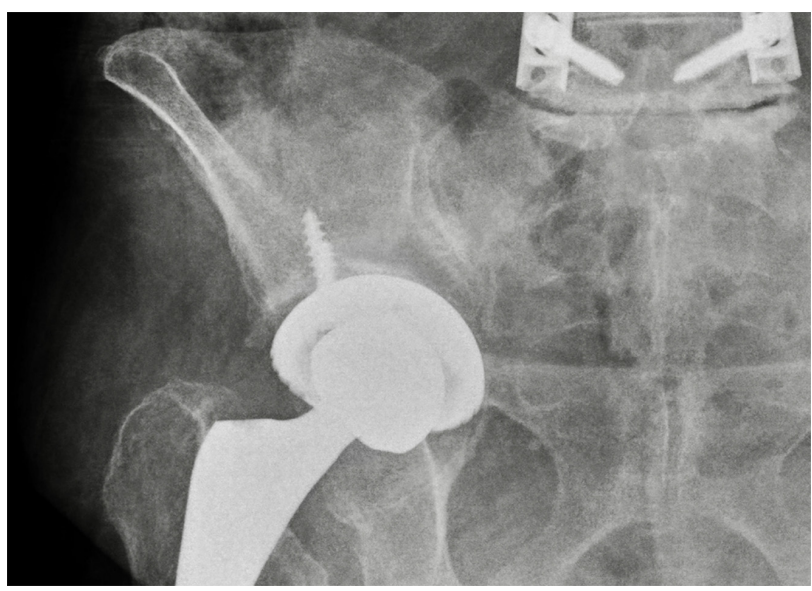

Şekil 6. Yetmiş altı yaşındaki kadın hasta, dört yıl önce primer kalça artriti tanısı ile çimentosuz total kalça artroplastisi (TKA) ameliyatı yapılmış. Kronik aktivite ile artan kasık ağrısı şikâyetiyle müracaat etti. İlk ameliyatından itibaren ağrısının devam ettiğini ve desteksiz yürüyemediğini belirtti. Fizik muayenesinde kalça hareketlerinde bir miktar ağrı dışında çok belirgin bir rahatsızlık yoktu. Röntgen grafisinde asetabular komponentin etrafında üst bölümünde gevşemeye işaret eden radyolüsen alanlar ve iliopektineal çizginin (medial duvarın) devamlılığını yitirdiği tespit edildi. Cerrahi sırasında asetabular kap gevşekti. Hasta revizyon cerrahisi ile tedavi edildi.

genellikle rahattırlar. Asetabular gevşeme tanısı konulursa revizyon cerrahisi gereklidir.

Femoral gevşeme durumunda da ciddi klinik sıkıntı mevcuttur. Hastaların ağrısı tipik olarak uyluk proksimal orta hat üzerindedir ve bazen femur boyunca dize doğru vurabilir. Hatta bazı hastalar, diz yakınması sebebiyle, gerekli olmayan diz cerrahisine bile maruz kalabilirler. İyi bir fizik muayenede ağrının lokalizasyonu ve rotasyonların ağrılı olması hekimi şüphelendirmelidir. Primer stabilitenin elde edilmesinde; kemik kalitesi, proksimal femurun anatomik özelliği, protez tasarımı ve malzeme özelliği ile uygun ölçü seçimi önemlidir. ${ }^{[16]}$ Gevşeme, direkt grafilerde görüntülenebilir (Şekil 7). Bu hastalarda, femoral stem etrafinda radyolusens alanlar görülmekle birlikte, sıklıkla femoral komponentin distale çökmesi de görülebilir (Şekil 8). Ağrı, asetabular komponentte olduğu gibi aktivite ile artar ve klinik tablo asetabular gevşemeden daha ağırdır. ${ }^{[12]}$ Aseptik femoral gevşemenin sebepleri; sıklıkla küçük boy seçimi, mevcut ciddi osteoporoz ve belki de ameliyat sırasında gelişen şüpheli bir iyatrojenik periprostetik kırık varlığıdır. Femoral gevşeme tanısı konulursa cerrahi revizyon gereklidir. Femoral kanal raspalanarak, daha büyük çimentosuz bir femoral komponent ile revizyon yapılabilir. Ciddi kemik kaybı olmadığından, çoğu olguda primer femoral komponent de kullanılabilir. 


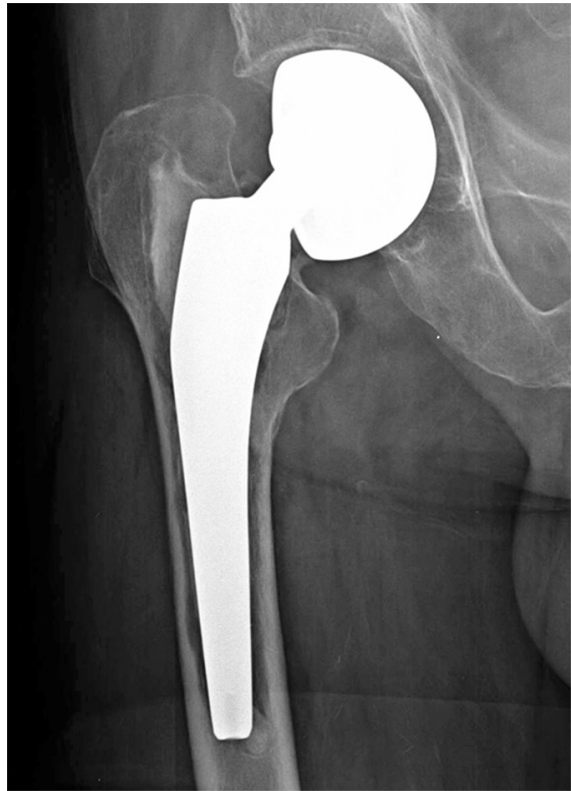

Şekil 7. Yetmiş yedi yaşındaki erkek hasta, yedi yıl önce kalça kırı̆̆ına bağlı çimentolu hemiartroplasti yapılmış. Son iki yıldır kalça ağrısının başladığı ve yürümekte zorlandığını ifade etti. Direkt grafide femoral komponentin tamamen gevşemiş olduğu görülmekte.

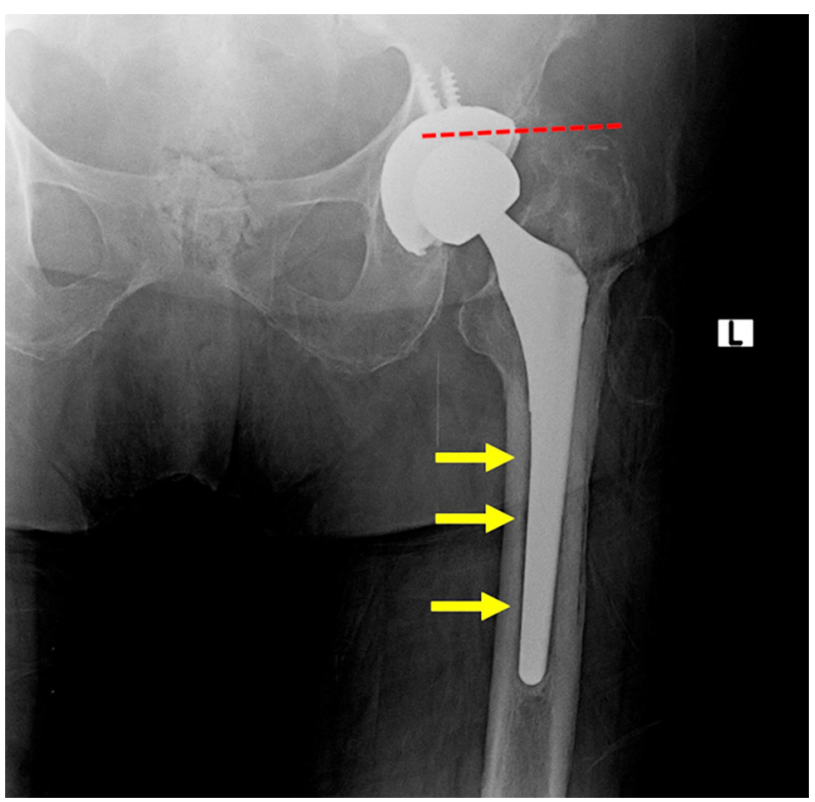

Şekil 8. Seksen bir yaşındaki kadın hastaya, iki yıl önce primer kalça artriti tanısı ile çimentosuz total kalça artroplastisi (TKA) ameliyatı yapılmış. Hasta, son bir yıldır zamanla artan kalça ağrısının başladığı ve yürümekte zorlandığını ifade etti. Fizik muayenede alt ekstremite rotasyonları çok ağrılı, ağıı özellikle femur orta hatta anteriorda lokalizeydi. Direkt grafide, femoral komponentin tamamen gevşemiş olduğu (sarı oklar) ve kanal içerisinde distale doğru yer değiştirdiği dikkat çekmekte (kırmızı çizgi). Hasta, izole femoral revizyon ameliyatı ile tedavi edildi.

(Şekil 11). Genellikle, direkt grafiler lezyonun ağırlığını ve sınırlarını olduğundan biraz daha az gösterir. Bu olgularda, BT'den ya da metal baskılama yapılmış MR görüntülemeden yararlanılarak lezyonun tam büyüklüğü ortaya konmalıdır. ${ }^{[8]}$ Ağrı ve konfor kaybına sebep olması, periprostetik kırık yapmış olması, aşırı genişlemiş osteoliz alanların varlığı ve komponentlerde instabilite durumlarında revizyon cerrahisi gereklidir.

\section{Materyal iliş̧kili Ağrılar}

Total kalça artroplastisi yapılan hastalarda trunnionosis, son yıllarda tanımlanan önemli bir başarısızlık sebebi olarak dikkat çekmektedir. Trunnionosis, femoral komponentin boyun bileşkesi ile metal baş arasında oluşan aşınmadan kaynaklanan bir tablodur. Sebebi tam bilinmez; ancak modüler tasarımlarda baş boyun birleşme yerinde aşınma, korozyon hasarı ve metal iyon salınımının rol oynayabileceği öne sürülmektedir. Değiş̧ik serilerde, revizyonların \%2-\%3'üne kadar varan oranlarda görüldüğü bildirilmiştir. ${ }^{[18,19]}$ Ağrılı kalça durumlarında trunnionosis de dikkate alınmalıdır. illk ameliyatta kullanılan 

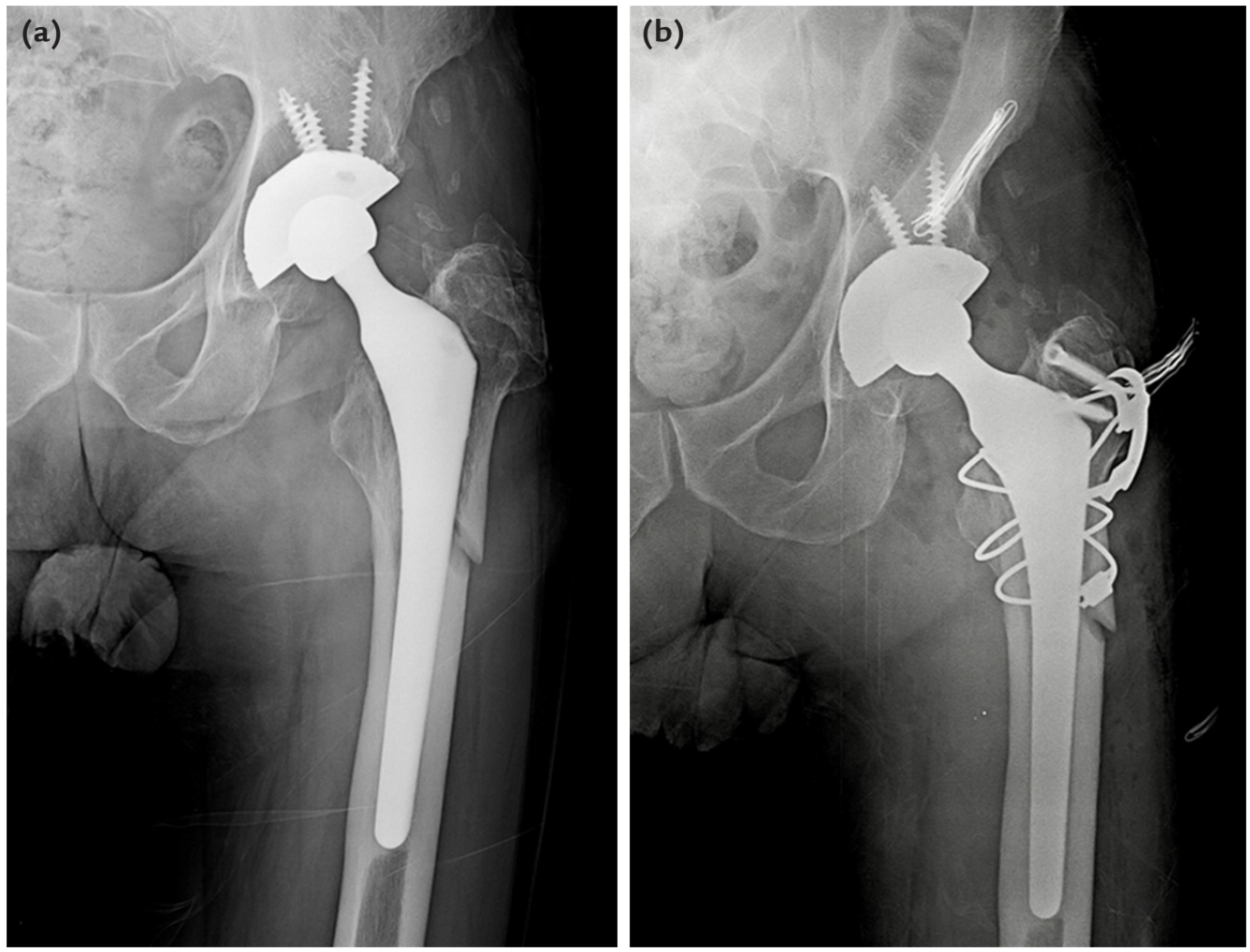

Şekil 9. a, b. Altmış üç yaşındaki erkek hastaya, 12 yıl önce primer kalça artriti tanısı ile çimentosuz total kalça artroplastisi (TKA) ameliyatı yapılmış. Hiçbir yakınması yokken, düşme sonrası lateral kalça ağrısı tanımlıyor. Grafisinde, trokanter majörü içerisine alan periprostetik kırık görülmekte (a). Femoral komponentin stabil olduğunun görülmesi üzerine hasta, izole kırık tespiti ile tedavi edildi (b).
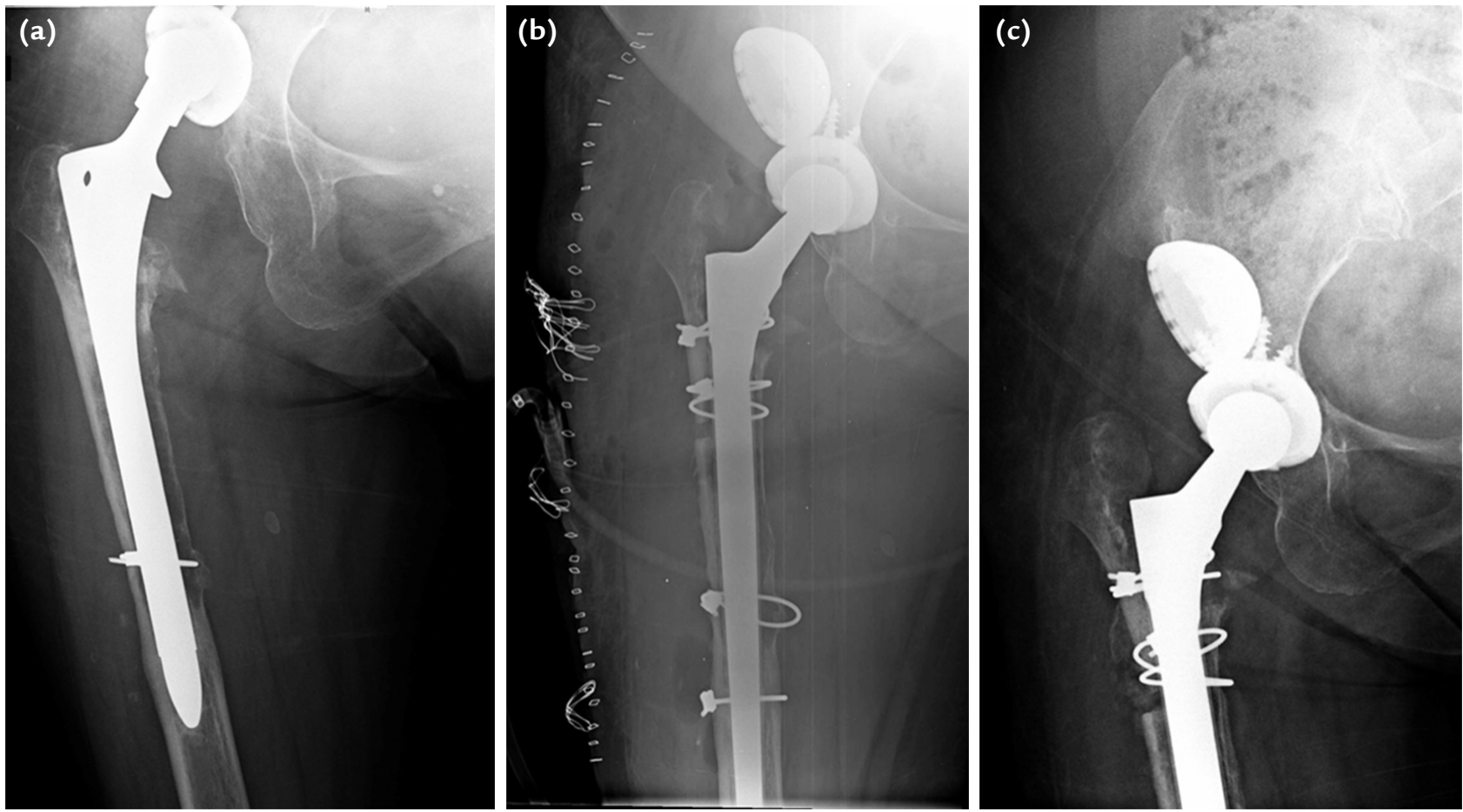

Şekil 10. a-c. Elli dokuz yaşındaki kadın hastaya, 11 yıl önce kalça çıkığı zemininde yüksekte asetabular kap yerleşimli çimentosuz total kalça artroplastisi (TKA) ameliyatı yapılmış. Son üç aydır şiddetli uyluk ve daha az derecede kasık ağrısı tanımlıyor. Son günlerde yürümesi tamamen zorlaşmış ve çift koltuk değneği kullanıyor. Direkt grafisinde, femoral komponentin medialinde yaygın osteoliz görülmekte (a). Hastanın kalçası, genişletilmiş trokanterik osteotomi sonrasında, uzun, distale doğru incelen (tapered) ve yekpare (modüler olmayan) femoral stem kullanılarak revize edildi (b). Asetabulum orijinal yerine indirildi. Daha önce yerleştirilen asetabular kap, kemiğe sağlam olarak tutunuyordu ve sökülmesi durumunda orijinal asetabulumda kemik kaybına neden olacağı düşüncesiyle, yerinde bırakıldı (c). Hastanın ameliyat öncesi şikâyetleri kısa sürede kayboldu. 


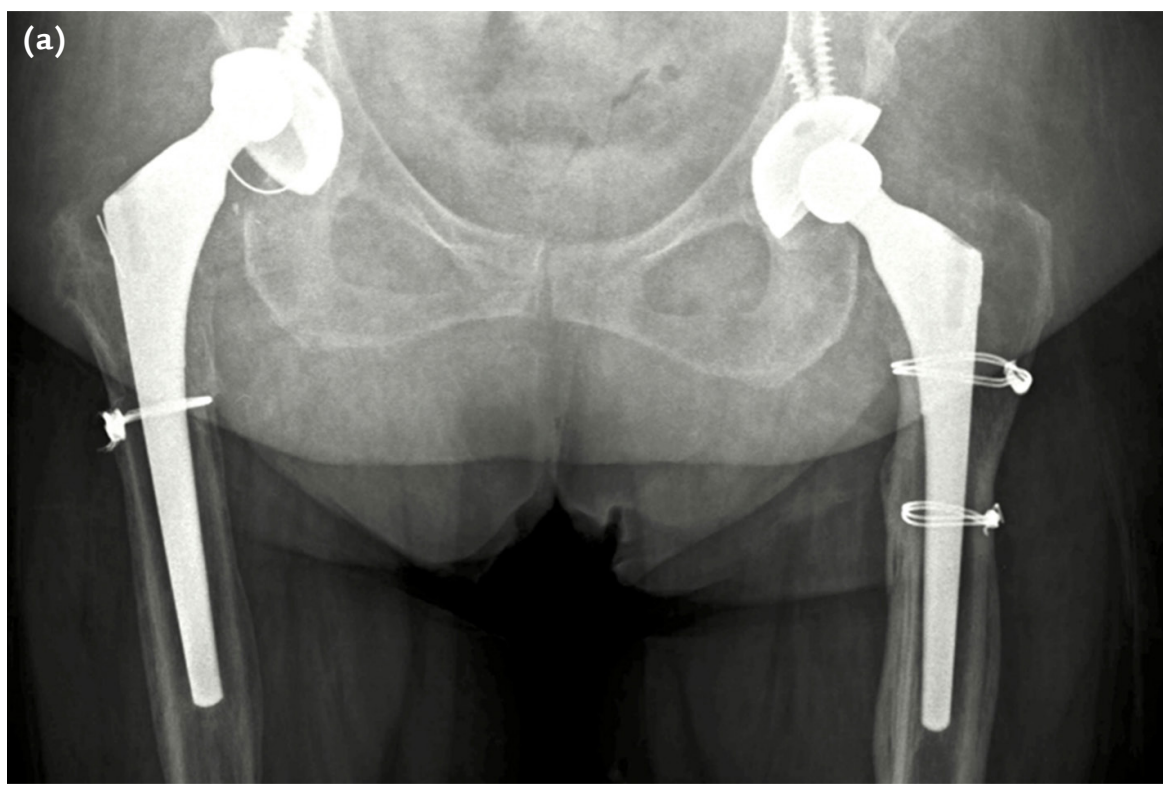

Şekil 11. a, b. Yetmiş bir yaşındaki kadın hastaya, 13 yıl önce kalça çıkığı zemininde çimentosuz total kalça artroplastisi (TKA) ameliyatı yapılmış. Son altı aydır kasık ağrısı ve zamanla artan yürüme güçlüğü tanımlıyor. Direkt grafisinde, sağ kalçadaki TKA'da femur başının eksantrik yerleştiği ve kalçada instabilite görüntüsü vardı (a). Hasta, sadece asetabular revizyon ameliyatı ile tedavi edildi. Cerrahi sırasında polietilen ara parçanın (insert) ciddi derecede aşındığı ve metal asetabular kapın, metal femur başı tarafindan ezildiği görülüyor (b).

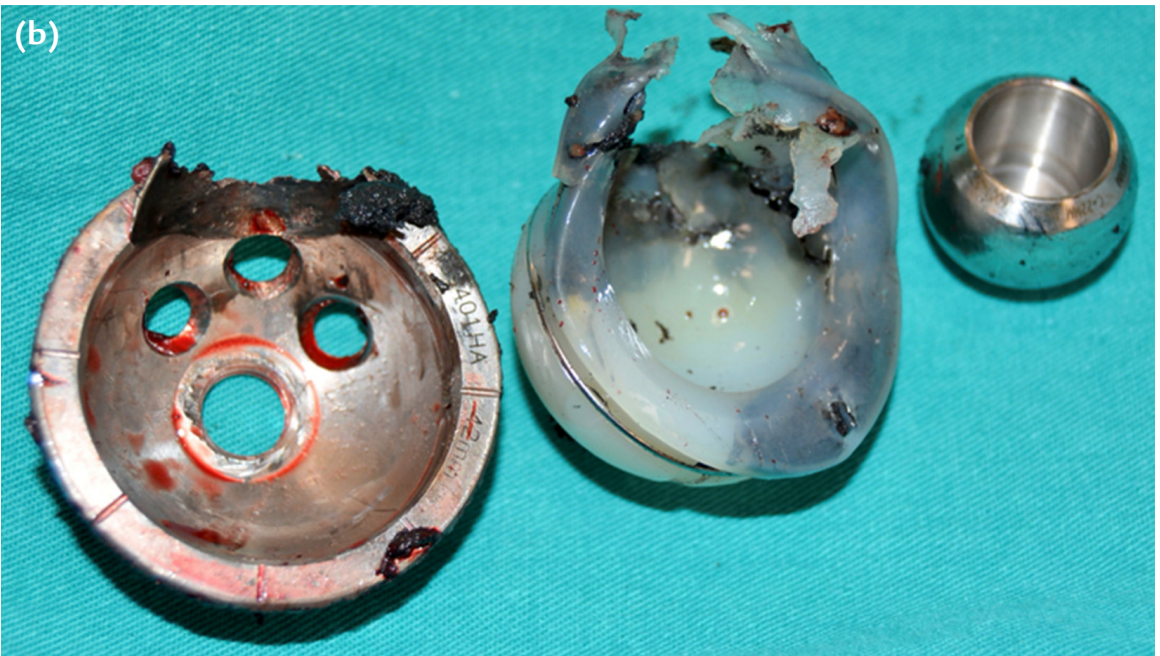

malzemelerin kaydı istenmeli ve malzemelerin birbirine uyum durumu, kullanılan baş, offset durumu ile protez tasarımı değerlendirilmelidir. Trunnionosis'ten sakınmak için; baş boyun düzeneğinin uygun şekilde sağlamlaştırılması, $36 \mathrm{~mm}$ ve daha küçük baş kullanımı, nötral offset, metal yerine seramik baş ya da nötral uzunlukta baş tercihleri önerilmektedir. ${ }^{[19]}$

Yine, ağrılı kalça durumlarının önemli bir sebebi de son yıllarda gündemde olan metal-metal protez uygulamalarıdır. Özellikle erkek hastalarda, uzun dayanım ve geniş eklem açıklığı hedeflenerek yönelinen metalmetal kullanımı, son yıllarda görülen kötü olgulardan ve çok ağır revizyonlara sebep olmasından dolayı gündemden düşmüştür. Metal eklemleşmelerden çevreye, toksik dozda krom ve kobalt iyonları ile metalik artıklar salınır. Bu durum, alışılagelmiş polietilen aşınmasından daha belirgindir. Salınan metal iyonları yumuşak dokuda yabancı doku reaksiyonu yapmakta, bu da çevre dokulara ve protez-kemik birleşimine zarar vermekte, psödotümör denilen büyük kitlelere sebep olmaktadır. Tüm bu klinik tabloya "adverse local tissue reaction" (ALTR) adı verilmektedir. ${ }^{[3,8,12]}$ Son serilerde, metal-metal revizyonlarda, \%27 oranında metal reaksiyonuna rastlandığı bildirilmektedir. ${ }^{[12,20]} \mathrm{Bu}$ tip durumlara, metal-politeilen eklemleşmelerde de rastlandığı bildirilmiştir. ${ }^{[21,22]}$

“Adverse local tissue reaction” görülme sıklığı, bazı geniş serilerde \%0,5 ile \%1,5 arasında bildirilmiştir. ${ }^{[22]}$ Metal-metal eklemleşme yapılan TKA hastalarında ağrılı kalçanın değerlendirilmesi zordur; metal hassasiyeti 

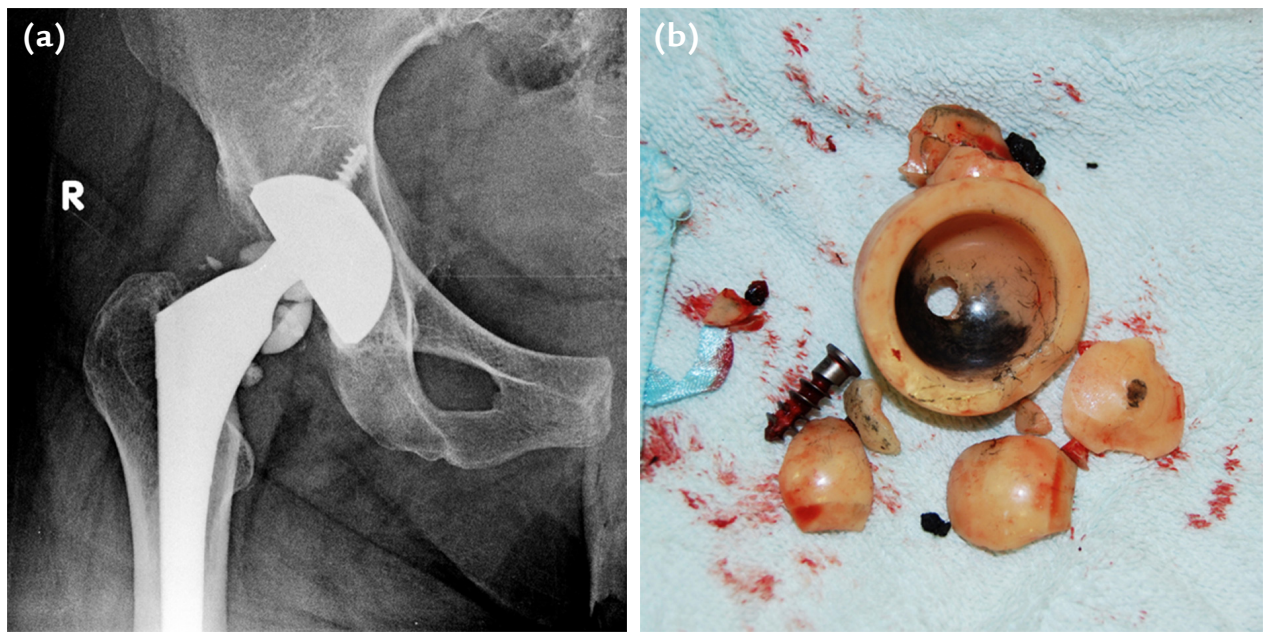

Şekil 12. a, b. Kırk yedi yaşındaki kadın hastaya, altı yıl önce kalça çıkığı zeminde seramik-seramik çimentosuz total kalça artroplastisi (TKA) ameliyatı yapılmış. Hiçbir şikâyeti yokken, ani bir hareketle kalçasında ağrı başlamış. Yürürken kalçasından ses geldiğini de ifade ediyor. Fizik muayenede kalça hareketlerinde kısıtlılık var ve kısmen krepitasyon alınıyor. Kalça grafisinde, seramik komponentin kırıldığı görülüyor (a). Revizyon cerrahisinde hem insert hem de başın kırıldığı görüldü (b). Femur ve asetabulum değiştirildi, polietilen-seramik eklemleşme tercih edildi.

ve aşınma dikkate alınmalıdır. Kobalt ve krom metal iyon seviyelerine bakılmalıdır; sedimantasyon ve CRP düzeyi çoğunlukla yüksektir. Metal baskılı MR görüntüleme, eklem çevresi hakkında bilgi verir ve mutlaka yapılmalıdır. Klinik durumu sıkıntılı olan ALTR tablolu hastalar, cerrahi olarak revize edilmelidir.

Seramik-seramik eklemleşmeli TKA'da, çok nadir de olsa ağrı olabilir. ${ }^{[5]}$ Özellikle, seramik komponentlerin travmatik ya da sıkışma sonrası kırılmalarında kalçada ağrı görülebilir ve gıcırtı gibi anormal sesler alınabilir (Şekil 12). Son yıllarda, malzeme kalitesinin iyileşmesi ile birlikte, seramik kırılmaları çok az görülmektedir.

\section{NADIR KALÇA AĞRISI NEDENLERi}

Kompleks bölgesel ağrı sendromu, eski adıyla Sudeck atrofisine bağlı ağrı tablosu, nadiren total eklem protezi ameliyatları sonrası ortaya çıkabilir. Özellikle, kalça protezi sonrası geçmeyen ve sebebi bulunamayan ağrılı kalçalarda dikkate alınmalıdır. $[6,8,23]$ Tanıda, klinik bulgular yanında; direkt grafilerdeki mineral kaybının gösterilmesi ve özellikle de üç fazlı kemik sintigrafisinde tipik bulguların ortaya konması yararlıdır. ${ }^{[23]}$ Tedavi multidisipliner olarak düzenlenmelidir.

Ağrılı kalça hastalarında, diyabet varlığı dikkate alınmalıdır. Aşırı kilo ve kontrolsüz diyabetin, TKA uygulamalarında komplikasyonları artırdığı iyi bilinmektedir. Bunun yanında, diyabet bazen kalıcı ve açıklanamayan ağrıla da ilişkili olabilir. Rajamäki ve ark., diz ve kalça artroplastisi yapılan hastalarda kalıcı ağrının \%14 oranında görüldüğünü ve bunun diyabetle ilişkili olduğunu, diyabetin kalıcı ağrı oluşumunda bir risk faktörü olduğunu rapor ettiler. Yazarlar, ağrının düşük dereceli bir enfeksiyonun ağrı duyarlılığını artırmış olabileceği yorumunu yapmışlardır. ${ }^{[24]}$

\section{KAYNAKLAR}

1. Kahlenberg CA, Nwachukwu BU, Schairer WW, Steinhaus ME, Cross MB. Patient Satisfaction Reporting After Total Hip Arthroplasty: A Systematic Review. Orthopedics 2017;40(3):e400-4. Crossref

2. Schmitz PP, van Susante JLC, Hol A, Brokelman R, van Loon CJM. No decline in high patient satisfaction after total hip arthroplasty at long-term follow-up. Eur J Orthop Surg Traumatol 2019;29(1):91-5. Crossref

3. Pivec R, Johnson AJ, Mears SC, Mont MA. Hip arthroplasty. Lancet 2012;380(9855):1768-77. Crossref

4. Lam YF, Chan PK, Fu H, Yan $\mathrm{CH}$, Chiu KY. A review of the clinical approach to persistent pain following total hip replacement. Hong Kong Med J 2016;22(6):600-7. Crossref

5. Henderson RA, Lachiewicz PF. Groin pain after replacement of the hip: aetiology, evaluation and treatment. J Bone Joint Surg Br 2012;94-B(2):145-51. Crossref

6. Erivan R, Villatte G, Ollivier M, Paprosky WG. Painful Hip Arthroplasty: What Should We Find? Diagnostic Approach and Results. J Arthroplasty 2019;34(8):1802-7. Crossref

7. Pacault-Legendre V, Anract P, Mathieu M, Courpied JP. Pain after total hip arthroplasty: a psychiatric point of view. Int Orthop 2009;33(1):65-9. Crossref

8. Bou Monsef J, Parekh A, Osmani F, Gonzalez M. Failed Total Hip Arthroplasty. JBJS Rev 2018;6(11):e3. Crossref 
9. Parvizi J, Della Valle CJ. AAOS clinical practice guideline: diagnosis and treatment of periprosthetic joint infections of the hip and knee. J Am Acad Orthop Surg 2010;18(12):771-2. Crossref

10. Higuera CA, Zmistowski B, Malcom T, Barsoum WK, Sporer SM, Mommsen P, Kendoff D, Della Valle CJ, Parvizi J. Synovial fluid cell count for diagnosis of chronic periprosthetic hip infection. J Bone Joint Surg Am 2017;99(9):753-9. Crossref

11. Parvizi J, Pour AE, Hillibrand A, Goldberg G, Sharkey PF, Rothman $\mathrm{RH}$. Back pain and total hip arthroplasty: a prospective natural history study. Clin Orthop Relat Res 2010;468(5):1325-30. Crossref

12. Henderson RA, Lachiewicz PF. Evaluation of the painful total hip arthroplasty. In: Cashman J, Goyal N, Parvizi J, editors. The Hip: Preservation, Replacement and Revision. Brooklandville: Data Trace; 2015. p. 95-1.

13. McGrory BJ, McGrory CP, Barbour L, Barbour B. Transient subluxation of the femoral head after total hip replacement. J Bone Joint Surg Br 2010;92(11):1522-6. Crossref

14. Engh CA, Hopper RH, Engh CA. Long-term porous-coated cup survivorship using spikes, screws, and press-fitting for initial fixation, J Arthroplasty 2004;19(2):254. Crossref

15. Tabata, T., Kaku, N., Hara, K. et al. Initial stability of cementless acetabular cups: press-fit and screw fixation interaction -an in vitro biomechanical study. Eur J Orthop Surg Traumatol 2015;25:497-502. Crossref

16. Kheir MM, Drayer NJ, Chen AF. An Update on Cementless Femoral Fixation in Total Hip Arthroplasty. J Bone Joint Surg Am 2020;102(18):1646-61. Crossref
17. Browne JA, Thakral R, Scott JM. Management of wear and osteolysis in total hip arthroplasty. In: Cashman J, Goyal N, Parvizi J. editors. The Hip: Preservation, Replacement and Revision. Brooklandville: Data Trace; 2015. p. 105-1.

18. Mistry JB, Chughtai M, Elmallah RK, Diedrich A, Le S, Thomas M, Mont MA. Trunnionosis in total hip arthroplasty: a review. J Orthop Traumatol 2016;17:1-6. Crossref

19. Berstock JR, Whitehouse MR, Duncan CP. Trunnion corrosion: what surgeons need to know in 2018. Bone Joint J 2018;100-B(1 Supple A):44-9. Crossref

20. Fitz D, Klemt C, Chen W, Xiong L, Yeo I, Kwon Y-M. HeadNeck Taper Corrosion in Metal-on-Polyethylene Total Hip Arthroplasty: Risk Factors, Clinical Evaluation, and Treatment of Adverse Local Tissue Reactions. J Am Acad Orthop Surg 2020;28(22):907-13. Crossref

21. Cipriano CA, Issack PS, Beksac B, Della Valle AG, Sculco TP, Salvati EA. Metallosis after metal-on-polyethylene total hip arthroplasty. Am J Orthop (Belle Mead NJ) 2008;37(2):E1825. https://pubmed.ncbi.nlm.nih.gov/18401490/

22. Carli A, Reuven A, Zukor DJ, Antoniou J. Adverse soft-tissue reactions around non-metal-on-metal total hip arthroplasty -a systematic review of the literature. Bull NYU Hosp Jt Dis 2011;69 Suppl 1:S47-51. https://pubmed.ncbi.nlm.nih.gov/22035485/

23. Zanotti G, Slullitel PA, Comba FM, Buttaro MA, Piccaluga F. Three cases of type- 1 complex regional pain syndrome after elective total hip replacement. SICOTJ 2017;3:52. Crossref

24. Rajamäki TJ, Jämsen E, Puolakka PA, Nevalainen PI, Moilanen $T$. Diabetes is associated with persistent pain after hip and knee replacement. Acta Orthop 2015;86(5):586-93. Crossref 